\title{
Evaluation of Olive as a Host of Xylella fastidiosa and Associated Sharpshooter Vectors
}

Rodrigo Krugner, Mark S. Sisterson, Jianchi Chen, and Drake C. Stenger, United States Department of Agriculture-Agricultural Research Service, San Joaquin Valley Agricultural Sciences Center, Parlier, CA 93648; and Marshall W. Johnson, Department of Entomology, University of California, Riverside 92521

\begin{abstract}
Krugner, R., Sisterson, M. S., Chen, J., Stenger, D. C., and Johnson, M. W. 2014. Evaluation of olive as a host of Xylella fastidiosa and associated sharpshooter vectors. Plant Dis. 98:1186-1193.

Olive (Olea europaea) trees exhibiting leaf scorch or branch dieback symptoms in California were surveyed for the xylem-limited, fastidious bacterium Xylella fastidiosa. Only approximately $17 \%$ of diseased trees tested positive for $X$. fastidiosa by polymerase chain reaction, and disease symptoms could not be attributed to X. fastidiosa infection of olive in greenhouse pathogenicity assays. Six strains of $X$. fastidiosa were isolated from olive in Southern California. Molecular assays identified strains recovered from olive as belonging to $X$. fastidiosa subsp. multiplex. Pathogenicity testing of olive strains on grapevine and almond confirmed that $X$. fastidiosa strains isolated from olive yield disease phenotypes on almond and grapevine typical of those expected for subsp. multiplex. Mechanical inoculation of $X$. fastidiosa olive strains to olive resulted in infection at low efficiency but in-

transmission assays demonstrated that glassy-winged sharpshooter (Homalodisca vitripennis) could transmit strains of both subspp. multiplex and fastidiosa to olive at low efficiency. Insect trapping data indicated that two vectors of $X$. fastidiosa, glassy-winged sharpshooter and green sharpshooter (Draeculacephala minerva), were active in olive orchards. Collectively, the data indicate that $X$. fastidiosa did not cause olive leaf scorch or branch dieback but olive may contribute to the epidemiology of $X$. fastidiosa-elicited diseases in California. Olive may serve as an alternative, albeit suboptimal, host of $X$. fastidiosa. Olive also may be a refuge where sharpshooter vectors evade intensive areawide insecticide treatment of citrus, the primary control method used in California to limit glassy-winged sharpshooter populations and, indirectly, epidemics of Pierce's disease of grapevine.
\end{abstract} fections remained asymptomatic and tended to be self-limiting. Vector
Diseases caused by the xylem-limited, fastidious bacterium $X y$ lella fastidiosa have been a problem in California for more than 100 years, with grapevine $(20,32)$, almond $(28,41,42)$, and alfalfa $(43,50)$ being the most affected crops. $X$. fastidiosa is widely distributed in the Americas, causing vascular occlusion disease in some host species while other host species remain asymptomatic $(22,26,38)$. Individual strains of $X$. fastidiosa differ in host range and may be classified into subspecies by multilocus sequence typing (MLST) (40,53). Strains of $X$. fastidiosa subsp. fastidiosa cause Pierce's disease of grapevine (14) and are capable of causing disease in other hosts, including almond (6). X. fastidiosa subsp. multiplex strains do not cause disease in grapevine but are commonly isolated from almond expressing leaf scorch disease $(6,7,15,28)$, and subsp. multiplex strains also cause disease in numerous perennial crop and landscape plants, including peach (13,51), plum (37), purple-leafed plum, and sweetgum (18). In South America, citrus variegated chlorosis and coffee leaf scorch are caused by strains of subsp. pauca $(1,5,17)$. Oleander leaf

Corresponding author: R. Krugner, E-mail: rodrigo.krugner@ars.usda.gov

Mention of trade names or commercial products in this publication is solely for the purpose of providing specific information and does not imply recommendation or endorsement by the United States Department of Agriculture (USDA). USDA is an equal opportunity provider and employer.

Accepted for publication 20 March 2014.

http://dx.doi.org/10.1094/PDIS-01-14-0014-RE

This article is in the public domain and not copyrightable. It may be freely reprinted with customary crediting of the source. The American Phytopathological Society, 2014. scorch $(8,36)$ is caused by strains belonging to a distinct clade referred to as subsp. sandyi.

$X$. fastidiosa is transmitted by xylem-sap-feeding leafhoppers $(28,33)$. Historically, the key native vectors in California were the blue-green sharpshooter (Graphocephala atropunctata Signoret) in Napa Valley (35) and green sharpshooter (Draeculacephala minerva Ball) in the San Joaquin Valley $(12,34,43)$. In the late 1980s, the glassy-winged sharpshooter (Homalodisca vitripennis (Germar)) was introduced to California $(4,45,46)$ and is now well established in Southern California and the southern San Joaquin Valley. Glassy-winged sharpshooter, a known vector of X. fastidiosa (2), is polyphagous (47) and highly mobile $(3,10,25)$. Establishment of glassy-winged sharpshooter in citrus was a primary factor in recent epidemics of Pierce's disease in Southern California (31) and the southern San Joaquin Valley $(29,30,44)$.

California is the sole producer of olive (Olea europaea L.) in the United States, with approximately 17,800 ha planted and a production value estimated at $\$ 130$ million per annum (49). Although most commercial production is located in the San Joaquin and Sacramento Valleys, olive trees are commonly planted throughout California as ornamental trees in urban and rural areas. In recent years, leaf scorch and branch dieback symptoms in olive became a concern to growers, homeowners, and landscape managers in California. Such symptoms are typical of those caused by X. fastidiosa, prompting us to investigate the role of $X$. fastidiosa in olive leaf scorch or branch dieback disease. Recently, multiple fungal species have been isolated from symptomatic trees in California, with pathogenicity of some fungal isolates demonstrated by experimental inoculation of olive (48). However, those experiments did not address pathogenicity of $X$. fastidiosa to olive. Furthermore, limited information is available concerning the role of olive as a source of $X$. fastidiosa $(9,19)$ and sharpshooter vectors $(11)$. Here, 
we describe studies designed to evaluate (i) prevalence of $X$. fastidiosa infection of olive in California, (ii) molecular typing of $X$. fastidiosa strains isolated from olive, (iii) pathogenicity of $X$. fastidiosa strains from olive, (iv) transmission of $X$. fastidiosa to olive by glassy-winged sharpshooter, and (v) activity of known insect vectors of $X$. fastidiosa in olive orchards.

\section{Materials and Methods}

Sampling olive for $\boldsymbol{X}$. fastidiosa. Sampling sites in urban areas and commercial orchards were determined by visual inspection to identify trees displaying leaf scorch or branch dieback symptoms. Symptoms were documented by photography. From October 2008 to September 2012, tissue samples were collected from 198 symptomatic olive trees found in Southern California (i.e., ornamental trees in San Diego, Orange, Riverside, Los Angeles, and Ventura Counties), the San Joaquin Valley (i.e., trees in commercial orchards in Kern, Tulare, and Fresno Counties), and the Sacramento Valley (i.e., ornamental trees in Yolo County). Samples were transported to the laboratory and screened for presence of $X$. fastidiosa by polymerase chain reaction (PCR) using primers RST31 and RST33, as described (27), and by culturing on PW medium (13). Axenic cultures recovered from olive and validated as $X$. fastidiosa by molecular methods (see below) were added to the United States Department of Agriculture-Agricultural Research Service San Joaquin Valley Agricultural Sciences Center $X$. fastidiosa collection stored at $-80^{\circ} \mathrm{C}$.

Molecular typing of $X$. fastidiosa strains. For molecular identification, genomic DNA was extracted (6) from 7- to 14-day-old cultures. Preliminary identification of subspecies affiliation was accomplished using the four-primer PCR assay (6), in which amplicon profile of subsp. fastidiosa may be distinguished from that of subsp. multiplex. Known strains of subsp. fastidiosa (Temecula) and multiplex (Dixon) were used as standards. Further characterization was accomplished using MLST (40). Genomic DNA of select olive-infecting strains isolated in this study (LM10, RH1, and Fillmore) and the RC75 strain isolated by others (kindly provided by A. Purcell) was used as a template for PCR amplification of pilU and seven housekeeping genes (cysG, gltT, holC, $m a l F$, leuA, nuoL, and petC). Amplified products were cloned into pGEMT-easy. A consensus sequence was determined for each amplicon based on sequences of three independent clones. For MLST, consensus sequences of all eight amplicons were concatenated into a single sequence (7,480 nucleotides) for each strain. Concatenated sequences of $X$. fastidiosa strains isolated from olive were aligned with concatenated sequences of select reference strains available in GenBank. The resulting multiple alignment was used as input data to generate a neighbor-joining tree based on 1,000 bootstrap replications. Nodes with bootstrap support of less than $50 \%$ were collapsed to polytomies. Concatenated sequences for $X$. fastidiosa subsp. pauca strain 9a5c was used as an outgroup to root the tree.

Mechanical inoculation of $X$. fastidiosa to olive. To determine whether strains of $X$. fastidiosa isolated from olive persist and cause disease in olive, six strains of $X$. fastidiosa isolated from olive were grown in pure culture and mechanically inoculated (21) to 1-year-old (approximately $30 \mathrm{~cm}$ in height) greenhouse-reared olive plants. Inocula were prepared from 7- to 10-day-old cultures as a turbid cell suspension of approximately $10^{8}$ cells $/ \mathrm{ml}$ in water. A small drop of inoculum ( $7 \mu \mathrm{l}$ ) (or water, for negative controls) was placed at three different locations of the main stem (bottom, middle, and top); the stem was pierced with a needle through each drop. In total, 30 plants (O. europaea L.) of each olive cultivar ('Mission', 'Manzanillo', 'Sevillano', 'Arbequina', 'Arbosana', 'Koroneiki', and 'Barouni') were inoculated with $X$. fastidiosa strain RH1 a total of four times between March and September 2009. In October 2009, a second group of 30 plants (Manzanillo) was inoculated with $X$. fastidiosa strain Fillmore. A third group of plants (Arbequina) was inoculated with strains RH1 (2 plants), LM10 (14 plants), and Fillmore (3 plants) in June 2011. A fourth group of plants (Arbequina) was inoculated with RH1 (5 plants),
LM10, (10 plants), Fillmore (5 plants), and Oceanside (5 plants) in October 2012. Each group of inoculated plants included mockinoculated plants as controls. All test plants were kept in an insectfree greenhouse and monitored over a period of 1 year for symptom development and presence of $X$. fastidiosa by PCR (using primers RST31 and RST33) and culturing.

Mechanical inoculation of $X$. fastidiosa to grapevine and almond. Pathogenicity tests in almond and grapevine were conducted to complement MLST typing. Strains identified as belonging to subsp. fastidiosa were expected to cause disease in grapevine and almond, whereas strains identified as subsp. multiplex were expected to cause disease in almond but not grapevine. $X$. fastidiosa strains isolated from olive in this study (RH1, LM10, Fillmore, and Oceanside) were mechanically inoculated to grapevine (Vitis vinifera L. 'Chardonnay'), almond (Prunus dulcis (Mill.) D.A. Webb 'Sonora'), and olive using the same inocula described above (i.e., fourth group of olive plants inoculated in October 2012). As positive controls, strains Temecula and Stag's Leap (subsp. fastidiosa) were inoculated to grapevine and strains M12 and Dixon (subsp. multiplex) were inoculated to almond. Strain M23 (subsp. fastidiosa) was inoculated to both grapevine and almond. Inocula were prepared and delivered to test plants as described above, except that test plants were inoculated only on a single date. As a negative control, groups of 2 to 10 plants per host species were mock inoculated with water. All test plants were kept in an insect-free screenhouse and monitored for 1 year for symptom development and presence of X. fastidiosa by PCR and culturing.

Glassy-winged sharpshooter transmission assays. Transmission assays were conducted to confirm that glassy-winged sharpshooter is a vector of $X$. fastidiosa strains isolated from olive. Laboratory colonies of glassy-winged sharpshooter were established and maintained as described by Krugner (23). Plants infected by mechanical inoculation (described above) were used as acquisition source plants. Source plants for reference strains Temecula and Stag's Leap (subsp. fastidiosa) were infected grapevines (Chardonnay). Source plants for reference strains Dixon and M12 (subsp. multiplex) were infected almond plants (Sonora) Almond was used as a source plant for strain M23 (subsp. fastidi$o s a$ ). Source plants used for X. fastidiosa strains isolated from olive in this study were almond (strains RH1 and Fillmore) or Arbequina olive (strain LM10). Source plants for $X$. fastidiosa olive strain Oceanside were not available, because no mechanically inoculated plants became infected. All source plants were verified as infected by PCR and culturing. Colony-reared adult glassywinged sharpshooters were given a 96-h acquisition access period (AAP) on source plants. At the end of the AAP, insects were transferred in groups of 10 to test plants (Arbequina olive grown in 3.8-liter pots) for a 96-h inoculation access period (IAP). Following the IAP, insects were removed; test plants were treated with a foliar application of insecticidal soap (Safer Brand Insect Killing Soap; Woodstream Corp.) and the systemic insecticide imidacloprid (Admire Pro; Bayer CropSciences) as a soil drench. To verify that colony insects were not contaminated with $X$. fastidiosa, groups of 10 adults not given an AAP on source plants were caged on test plants for a 96-h IAP. To verify that test plants were not contaminated with $X$. fastidiosa from the source nursery, test plants not exposed to glassy-winged sharpshooters also were maintained in the same insect-free greenhouse as inoculated test plants. Inoculated and control test plants were maintained at 23 to $27^{\circ} \mathrm{C}$ and 22 to $25 \%$ relative humidity under natural light during summer and supplemented with artificial light during early spring, late fall, and winter. Plants were assayed for presence of $X$. fastidiosa at 12 and 24 weeks post IAP using PCR and culturing methods described above. On each sampling date, one leaf with petiole intact was collected from the bottom, middle, and top of each plant and subjected to analysis.

Insect vector activity in olive orchards. To document activity of insect vectors of $X$. fastidiosa in olive orchards, yellow card sticky traps (14 by $22.9 \mathrm{~cm}$; Seabright Laboratories) were moni- 

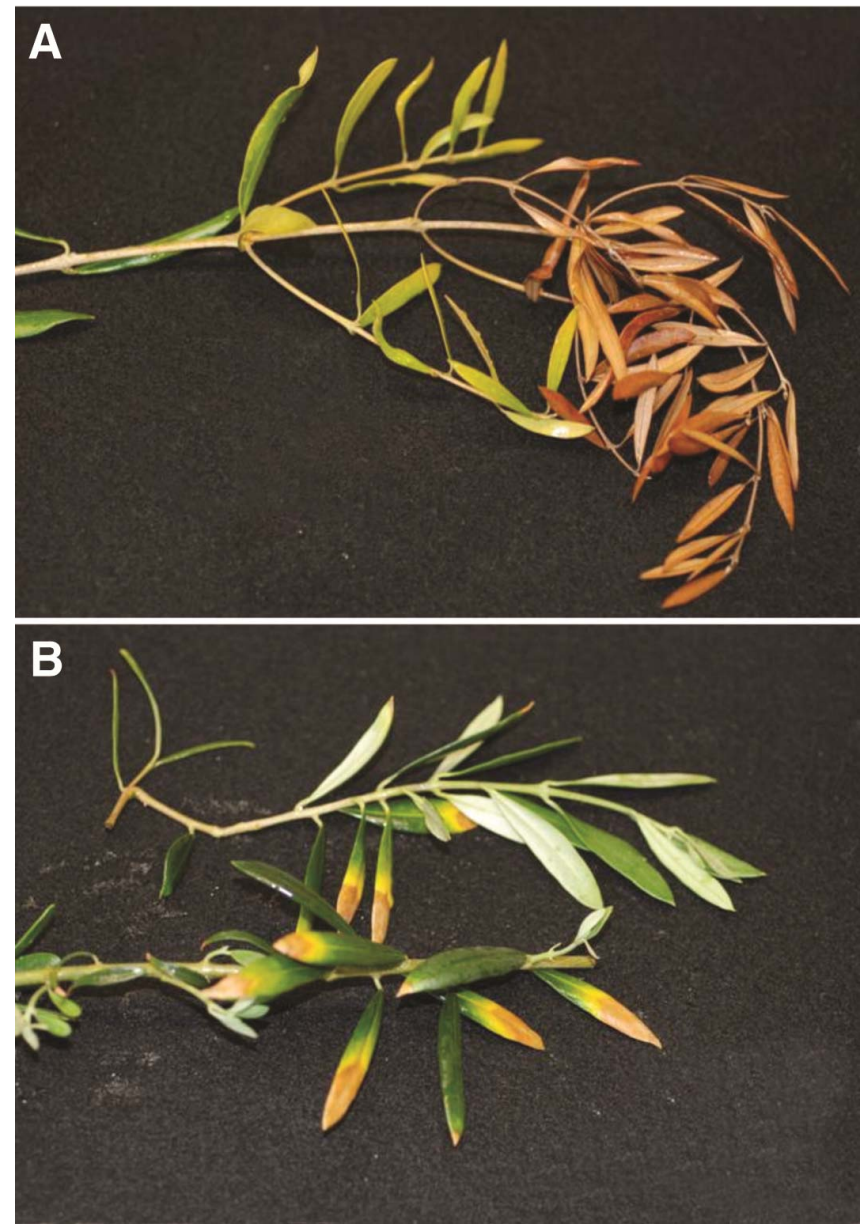

Fig. 1. A, Branch dieback and B, leaf scorch symptoms observed in olive trees sampled for $X y l e l l a$ fastidiosa in California. Note that $X$. fastidiosa was cultured from both samples shown but correlation of $X$. fastidiosa with symptoms in olive was low. tored in two olive orchards. Both orchards were located in Fresno County, CA. Site A was planted in 2003 and consisted of Arbequina, Arbosana, and Koroneiki. Site B was planted in 2009 and consisted of Arbequina and Arbosana. Site A was located within a known glassy-winged sharpshooter-infested zone. Site B was located outside the glassy-winged sharpshooter-infested zone, near permanent pastures known to harbor populations of green sharpshooters (43). Traps were placed at canopy height and replaced biweekly. At time of collection, the number of glassy-winged sharpshooters and green sharpshooters on each trap were recorded Trapping at site A was initiated in March 2010 and ended in September 2013. Trapping at site B was initiated in March 2011 and ended August 2013. Traps at site A were placed along five transects, with a total of 26 traps placed in the orchard. At site B, 14 traps were placed around the perimeter of the orchard. Traps were removed from both sites in late October through November of each year during harvest. No insecticides were applied to either orchard during the study period. Herbicides and fungicides were applied in accordance with standard grower practices.

\section{Results}

Prevalence of $X$. fastidiosa in olive in California. Samples were collected from olive trees displaying branch dieback (Fig. 1A) or leaf scorch (Fig. 1B) symptoms. Symptoms observed on ornamental trees in urban areas in southern California were similar to symptoms observed on trees in commercial orchards in the San Joaquin Valley and Yolo County. In total, samples were collected from 198 olive trees, with $X$. fastidiosa detected by PCR in $16.6 \%$ of samples (Table 1). Prevalence of $X$. fastidiosa was greater in Southern California than in the San Joaquin Valley or Yolo County. Specifically, 38.5\% (30 of 78) of symptomatic trees sampled in Southern California tested positive for $X$. fastidiosa by PCR, whereas only $2.5 \%$ (3 of 121) of symptomatic trees sampled in the San Joaquin Valley and Yolo County tested positive for $X$. fastidiosa by PCR (Table 1).

In total, six strains of $X$. fastidiosa were isolated from olive trees at several locations in Southern California: La Mirada (strains LM10 and LM14), Rolling Hills (strains RH1 and RH2), Fillmore (strain Fillmore), and Oceanside (strain Oceanside) (Table 1). The

Table 1. Survey of olive for Xylella fastidiosa in California

\begin{tabular}{|c|c|c|c|c|}
\hline Collection date & County & Location & Samples positive by $\mathbf{P C R}^{\mathrm{a}}$ & Number of $X$. fastidiosa strains isolated \\
\hline May 2009 & Yolo & Davis & $0 / 4$ & 0 \\
\hline June 2010 & Fresno & Fresno & $0 / 10$ & 0 \\
\hline July 2011 & & Fresno & $0 / 20$ & 0 \\
\hline July 2011 & & Fresno & $0 / 6$ & 0 \\
\hline July 2012 & & Clovis & $0 / 26$ & 0 \\
\hline August 2008 & Tulare & Porterville & $0 / 3$ & 0 \\
\hline August 2008 & & Terra Bella & $0 / 2$ & 0 \\
\hline August 2009 & & Ducor (site 1) & $0 / 10$ & 0 \\
\hline August 2009 & & Ducor (site 2) & $3 / 10$ & 0 \\
\hline June 2011 & & Woodlake & $0 / 3$ & 0 \\
\hline June 2011 & & Lemon Cove & $0 / 4$ & 0 \\
\hline June 2011 & & Lindsay & $0 / 16$ & 0 \\
\hline August 2008 & Kern & Bakersfield & $0 / 7$ & 0 \\
\hline August 2009 & Ventura & Piru & $2 / 5$ & 0 \\
\hline August 2009 & & Fillmore & $1 / 7$ & 1 \\
\hline August 2009 & & Ventura & $3 / 3$ & 0 \\
\hline October 2008 & Los Angeles & Rolling Hills & $0 / 5$ & 1 \\
\hline April 2009 & & Rolling Hills & $3 / 3$ & 1 \\
\hline March 2009 & & Rancho Bernardo & $3 / 3$ & 0 \\
\hline May 2011 & & La Mirada & $6 / 17$ & 2 \\
\hline May 2009 & Orange & Newport Beach & $2 / 8$ & 0 \\
\hline May 2009 & & Costa Mesa & $1 / 7$ & 0 \\
\hline May 2009 & Riverside & Riverside & $0 / 9$ & 0 \\
\hline August 2009 & & Riverside & $5 / 6$ & 0 \\
\hline May 2009 & San Diego & Carlsbad & $3 / 3$ & 0 \\
\hline October 2012 & & Oceanside & $1 / 1$ & 1 \\
\hline
\end{tabular}

${ }^{a}$ Numerator denotes number of plants positive by polymerase chain reaction (PCR) and denominator denotes number of plants tested. 
Fillmore strain was isolated from an olive tree present in a single row located between two mature citrus orchards; all other oliveinfecting strains were isolated from ornamental trees located in urban settings. Each culture was verified as $X$. fastidiosa based on
PCR (with primers RST31 and RST33) using genomic DNA extracted from cultures. Attempts to isolate strains of $X$. fastidiosa from olive trees in the San Joaquin Valley or Yolo County were unsuccessful.

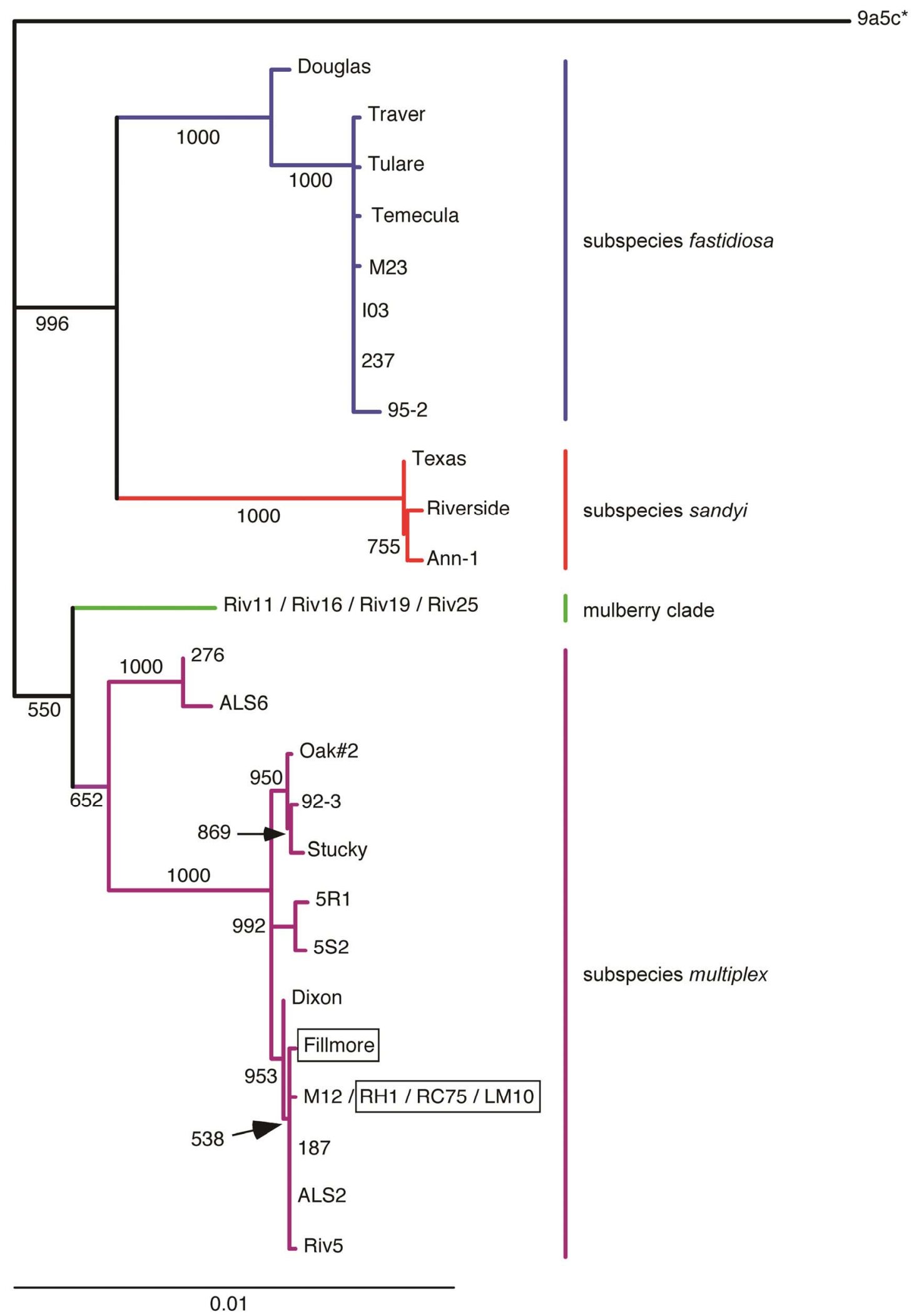

Fig. 2. Xylella fastidiosa strains isolated from olive in California belong to subspecies multiplex. Presented is a neighbor-joining tree showing relationships of $X$. fastidiosa strains from olive (RH1, LM10, Fillmore, and RC75; designated with boxes) with characterized reference strains of $X$. fastidiosa. Input data were a multiple alignment of concatenated sequences (7,480 nucleotides) for seven housekeeping genes and pilU. Multiple taxa appearing on a single branch were $100 \%$ identical in sequence. Colored lines denote individual clades, some of which have been assigned as subspecies. Bootstrap values (based on 1,000 replications) are shown adjacent to nodes; $X$. fastidiosa subsp. pauca strain $9 \mathrm{a} 5 \mathrm{c}$ is designated with an asterisk and was used as an outgroup to root the tree. Scale bar at bottom left indicates a genetic distance of 0.01 . 
$X$. fastidiosa strains from olive belong to subsp. multiplex. Preliminary typing using the four-primer assay (6) indicated that the six $X$. fastidiosa strains isolated from olive in this study were indistinguishable from reference strains of subsp. multiplex and distinct from reference strains of subsp. fastidiosa (data not shown). MLST was performed on a subset of strains isolated from olive (LM10, RH1, and Fillmore) in this study and strain RC75 (provided by A. Purcell), also isolated from olive in California. Sequences determined in this study were deposited in GenBank as accessions KF954183 to KF954214. Alignment of concatenated sequences for the eight loci examined revealed that LM10, RH1, and RC75 were $100 \%$ identical to each other and to subsp. multiplex reference strain M12; the Fillmore strain differed from M12 at only 2 base positions ( $99.97 \%$ identity). In the neighborjoining tree (Fig. 2) based on an alignment of concatenated sequences, the four olive-infecting strains clustered with known strains of subsp. multiplex in a clade distinct from subsp. fastidiosa, subsp. sandyi, and a clade containing strains from mulberry.

$X$. fastidiosa strains from olive yield disease phenotypes on almond and grapevine typical of those expected for subsp. multiplex. Inoculation of almond with $X$. fastidiosa strains isolated from olive or reference strains of subsp. multiplex resulted in a high correlation among symptoms (leaf scorch), detection by PCR, and isolation of the bacterium by culturing (Table 2 ). In contrast to reference strains of subsp. fastidiosa, inoculation of grapevine with $X$. fastidiosa strains from olive did not produce symptoms. Further-

Table 2. Mechanical inoculation of Xylella fastidiosa strains to three test species $^{\mathrm{a}}$

\begin{tabular}{|c|c|c|c|}
\hline Strain (subspecies), assay & Grapevine & Almond & Olive \\
\hline \multicolumn{4}{|l|}{ Temecula (fastidiosa) } \\
\hline Symptoms & $1 / 5$ & NT & NT \\
\hline PCR & $1 / 5$ & NT & NT \\
\hline Culture & $1 / 5$ & NT & NT \\
\hline \multicolumn{4}{|l|}{ Stag's Leap (fastidiosa) } \\
\hline Symptoms & $9 / 20$ & NT & NT \\
\hline PCR & $7 / 20$ & NT & NT \\
\hline Culture & $7 / 20$ & NT & NT \\
\hline \multicolumn{4}{|l|}{ M23 (fastidiosa) } \\
\hline Symptoms & $12 / 20$ & $3 / 10$ & NT \\
\hline PCR & $8 / 20$ & $3 / 10$ & NT \\
\hline Culture & $9 / 20$ & $3 / 10$ & NT \\
\hline \multicolumn{4}{|l|}{ Dixon (multiplex) } \\
\hline Symptoms & NT & $8 / 10$ & NT \\
\hline PCR & NT & $8 / 10$ & NT \\
\hline Culture & NT & $8 / 10$ & NT \\
\hline \multicolumn{4}{|l|}{ M12 (multiplex) } \\
\hline Symptoms & NT & $12 / 14$ & NT \\
\hline PCR & NT & $9 / 14$ & NT \\
\hline Culture & NT & $9 / 14$ & NT \\
\hline \multicolumn{4}{|l|}{ LM10 (multiplex) } \\
\hline Symptoms & $0 / 5$ & $1 / 9$ & $3 / 24^{\mathrm{b}}$ \\
\hline PCR & $0 / 5$ & $1 / 9$ & $2 / 24^{c}$ \\
\hline Culture & $0 / 5$ & $1 / 9$ & $0 / 24$ \\
\hline \multicolumn{4}{|l|}{ RH1 (multiplex) } \\
\hline Symptoms & $0 / 5$ & $7 / 14$ & $15 / 217^{b}$ \\
\hline PCR & $0 / 5$ & $6 / 14$ & $6 / 217^{c}$ \\
\hline Culture & $0 / 5$ & $6 / 14$ & $0 / 217$ \\
\hline \multicolumn{4}{|l|}{ Fillmore (multiplex) } \\
\hline Symptoms & $0 / 8$ & $3 / 8$ & $0 / 38$ \\
\hline PCR & $0 / 8$ & $1 / 8$ & $0 / 38$ \\
\hline Culture & $0 / 8$ & $1 / 8$ & $0 / 5$ \\
\hline \multicolumn{4}{|l|}{ Oceanside (multiplex) } \\
\hline Symptoms & $0 / 1$ & $0 / 4$ & $0 / 5$ \\
\hline PCR & $0 / 1$ & $0 / 4$ & $0 / 5$ \\
\hline Culture & $0 / 1$ & $0 / 4$ & $0 / 5$ \\
\hline
\end{tabular}

${ }^{a}$ Numerator denotes number of plants with symptoms or positive for $X$. fastidiosa by polymerase chain reaction (PCR) or culturing; denominator denotes number of plants tested; NT $=$ not tested.

${ }^{\mathrm{b}}$ Expressing leaf scorch or branch dieback symptoms but negative for $X$. fastidiosa by PCR.

${ }^{\mathrm{c}}$ Positive for $X$. fastidiosa by PCR but asymptomatic. more, all grapevines inoculated with $X$. fastidiosa olive strains were negative by PCR and did not yield live cultures. Collectively, pathogenicity tests using grapevine and almond as test hosts supported placement of $X$. fastidiosa strains isolated from olive in subsp. multiplex.

$X$. fastidiosa infection of olive does not correlate with disease symptoms. Field surveys resulted in detection of $X$. fastidiosa from approximately $17 \%$ of symptomatic trees tested. In greenhouse studies (Table 2), only 8 of 284 olive trees inoculated with $X$. fastidiosa strains RH1, Fillmore, LM10, or Oceanside tested positive by PCR for $X$. fastidiosa. However, no olive test plants positive for $X$. fastidiosa by PCR developed symptoms. Leaf scorch symptoms were observed on 22 olive test plants: 18 test trees inoculated with $X$. fastidiosa (but PCR-negative) and 4 test trees mock inoculated with water. Even after multiple attempts, $X$. fastidiosa was not detected by PCR or cultured from any olive test plant displaying symptoms. Collectively, the results indicate that leaf scorch or branch dieback symptoms of olive were not well correlated with $X$. fastidiosa infection in the field and were not reproducible by inoculation of $X$. fastidiosa to olive under controlled conditions in the laboratory.

$X$. fastidiosa infection of olive may be transient rather than chronic. Among test plants inoculated with $X$. fastidiosa olive strain RH1, two, one, one, and two test plants of Arbequina, Arbosana, Mission, and Barouni, respectively, tested positive for presence of $X$. fastidiosa via PCR conducted at 12 weeks post inoculation. However, no test plants inoculated with strain RH1 tested positive for the bacterium at 24 weeks and 1 year after inoculation. In addition, none of the plants inoculated with the Fillmore strain tested positive for the bacterium via PCR at 12 weeks, 24 weeks, and 1 year after inoculation. Two test plants (Arbequina) inoculated with strain LM10 tested positive by PCR for $X$. fastidiosa at 12 weeks, 24 weeks, and 1 year after inoculation. Despite repeated detection by PCR of the LM10 strain over a 1 -year period, both infected test plants did not express branch dieback or leaf scorch symptoms. No other olive test plants were positive for $X$. fastidiosa via PCR. All attempts to reisolate $X$. fastidiosa from inoculated olive test plants failed. Collectively, these results suggest that $X$. fastidiosa infection of olive may be selflimiting, such that chronic infection may be uncommon.

Glassy-winged sharpshooter transmits $X$. fastidiosa to olive at low efficiency. On average, 9.6 (range 6 to 10) insects per plant were alive at the end of the 96-h IAP on olive test plants. At 24 weeks after the IAP, branch dieback symptoms were observed in nine test plants, including one control plant that was not exposed to insects. However, all symptomatic test plants were negative for presence of $X$. fastidiosa via PCR. At 24 weeks after the IAP, $X$. fastidiosa was detected in a total of 6 of 145 test plants (Table 3). Among $X$. fastidiosa-positive test plants, one had been exposed to insects that acquired strain RH1, three plants had been exposed to insects that acquired the subsp. multiplex reference strain Dixon, and two plants had been exposed to insects that acquired the subsp. fastidiosa reference strain M23. No other asymptomatic plant tested positive for presence of $X$. fastidiosa via PCR and all attempts to reisolate the bacterium from glassy-winged sharpshooterinoculated olive test plants failed.

Table 3. Glassy-winged sharpshooter transmission assays of Xylella fastidiosa strains to olive test plants

\begin{tabular}{lcc}
\hline Strain (subspecies) & Acquisition source & Test plant PCR \\
\hline Temecula (fastidiosa) & Grapevine & $0 / 11$ \\
Stag's Leap (fastidiosa) & Grapevine & $0 / 25$ \\
M23 (fastidiosa) & Almond & $2 / 26$ \\
Dixon (multiplex) & Almond & $3 / 26$ \\
M12 (multiplex) & Almond & $0 / 27$ \\
LM10 (multiplex) & Olive & $0 / 4$ \\
RH1 (multiplex) & Almond & $1 / 26$ \\
\hline
\end{tabular}

\footnotetext{
${ }^{a}$ Numerator denotes number of plants positive for $X$. fastidiosa by polymer-
} ase chain reaction (PCR) and denominator denotes number of plants tested. 
Sharpshooter vectors are active in olive orchards. Yellow sticky trap counts revealed presence and activity of glassy-winged sharpshooter and green sharpshooter in two olive orchards located in Fresno County. Although glassy-winged sharpshooters were common at site A (Fig. 3A), only three green sharpshooters were caught (2 June 2010, 13 December 2010, and 20 June 2011) during the 4-year sampling period. Therefore, only data for glassy-winged sharpshooters are presented in Figure 3A. At site A, glassy-winged sharpshooters were common between June and August, and peaked with an average ( \pm standard error of the mean) of $0.08 \pm 0.02(n=$ $29), 0.10 \pm 0.03(n=55), 0.03 \pm 0.01(n=10)$, and $0.03 \pm 0.01(n$ $=11$ ) adults per trap per day in 2010, 2011, 2012, and 2013, respectively. Site B was not located inside a known glassy-winged sharpshooter-infested zone and, as expected, no glassy-winged sharpshooters were observed. Site B was located adjacent to a permanent pasture known to harbor green sharpshooters. The number of green sharpshooters caught at site B was low, with no clear seasonal patterns (Fig. 3B), a result similar to that reported for green sharpshooter movement into almond orchards and vineyards (12). In total, 17, 12, and 1 green sharpshooter were caught on sticky traps in 2011, 2012, and 2013, respectively. Green sharpshooters prefer grasses over woody perennials (34). Accordingly, movement of green sharpshooters into olive is likely transient and may have been due to proximity of a permanent pasture serving as a green sharpshooter source habitat.

\section{Discussion}

The role of $X$. fastidiosa in etiology of olive leaf scorch and branch dieback in California. Correlation of $X$. fastidiosa infection with leaf scorch or branch dieback symptoms of olive was poor in both the field survey and greenhouse pathogenicity or vector transmission assays. These observations indicated that $X$. fastidiosa strains reported here did not cause leaf scorch or branch dieback disease in olive maintained under the described conditions. Furthermore, in greenhouse assays, there was no overlap in olive test plants expressing symptoms with olive test plants in which presence of the pathogen was detected by PCR (Table 2). Several explanations for the presence of symptoms in test plants (including mock-inoculated plants) lacking detectable $X$. fastidiosa are plausible: some nursery-grown test plants may have been infected with a pathogen capable of causing disease in olive (48), or symptoms observed in some test plants were due to abiotic stress (drought) during the extended post inoculation incubation period. Such confounding issues are not unknown in studies of pathogens (such as $X$. fastidiosa) of perennial hosts that have a long incubation period and cause symptoms by interruption of xylem sap flow.

Under greenhouse conditions, establishment and multiplication of $X$. fastidiosa strains in olive by mechanical inoculation methods or insect transmission occurred at low frequency. By comparison, inoculation of grape or almond with reference strains and select olive-infecting strains resulted in a much higher correlation of symptom expression, pathogen detection by PCR, and recovery by culturing. These observations indicate that the strains of $X$. fastidiosa isolated from olive behaved as expected for subsp. multiplex genotypes. Therefore, limited infection rates, lack of persistence of the pathogen over time, and absence of disease symptoms in olive may be considered the result of pathogen-host interactions specific to olive. Because some olive plants were inoculated with the same inocula used to infect almond, low infectivity and lack of disease symptoms in olive cannot be explained as a general loss of pathogenicity in culture. Thus, olive may be considered a host in which $X$. fastidiosa acts similar to an endosymbiont, as has been shown for common riparian plants (35) and Arabidopsis thaliana (38), in which infected plants remain asymptomatic and bacterial populations are limited. However, additional data on the fate of $X$. fastidiosa in olive trees under field conditions over a period of years are needed to address this hypothesis.

Three species of fungi were identified as causal agents of olive twig and branch dieback in California (48). However, nothing is known about the causal agent of leaf scorching symptoms. Because
$X$. fastidiosa was found in trees showing twig and branch dieback, leaf scorching, or both symptoms, further studies are needed to evaluate whether co-infection by fungal pathogens and $X$. fastidiosa alters symptom expression.

The role of olive in epidemiology of diseases caused by $X$. fastidiosa. Although X. fastidiosa did not cause olive leaf scorch or branch dieback disease, olive may, under certain circumstances, serve as a reservoir for $X$. fastidiosa. In Southern California, X. fastidiosa infection of olive was common (Table 1), such that olive may contribute to incidence of $X$. fastidiosa in ornamental and landscape perennials susceptible to infection by strains of subsp. multiplex. Higher incidence of $X$. fastidiosa in olive in Southern California may be attributed to high population levels of the glassy-winged sharpshooter, which has a restricted range in the San Joaquin Valley. In the San Joaquin Valley, where most almond production occurs, infection of olive by $X$. fastidiosa was uncommon (Table 1). This observation suggests a limited contribution of olive as a source of $X$. fastidiosa inocula for the expansive almond industry in the San Joaquin Valley, even though strains of $X$. fastidiosa isolated from olive can experimentally cause almond leaf scorch disease (Table 2).

The glassy-winged sharpshooter can reproduce (R. Krugner, unpublished) and overwinter (11) on olive. Although population densities of glassy-winged sharpshooter can be considerably variable among host plant species (52), population dynamics of glassywinged sharpshooter observed in olive was similar to those reported in other hosts and locations in California. In general, there

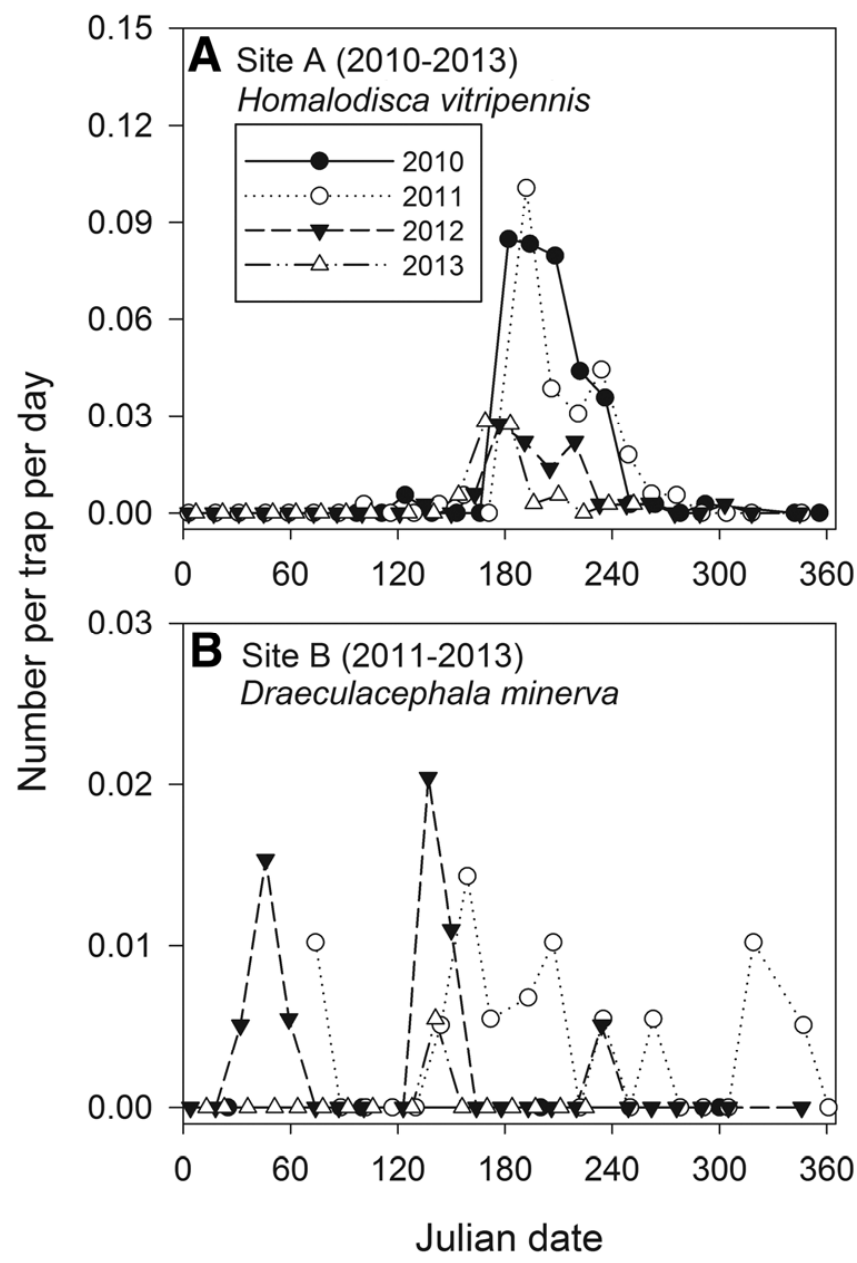

Fig. 3. Sharpshooter vector activity in olive orchards. A, Number of glassy-winged sharpshooters captured per trap per day from 2010 to 2013 at site A. Three green sharpshooters also were captured at site A during the trapping period (2 June 2010, 13 December 2010, and 20 June 2011). B, Number of green sharpshooters captured per trap per day from 2011 to 2013 at site B. No glassy-winged sharpshooters were caught at site $B$. 
is an increase in adult sharpshooter levels from late June to a peak in mid- to late July consistent with the appearance of first-generation adult emergence (24). Furthermore, trapping data from Fresno County (Fig. 3A) clearly indicate that glassy-winged sharpshooters are active in olive plantings. Thus, olive may contribute indirectly to the epidemiology of Pierce's disease by providing a refuge for glassy-winged sharpshooters. In contrast, green sharpshooter movement into olive was transient (Fig. 3B), suggesting that olive is unlikely to serve as a source of green sharpshooter.

California represents a mosaic of urban areas and regions of intensive, diverse agriculture in which $X$. fastidiosa, numerous hosts, and associated sharpshooter vectors are widely distributed, complicating management of vector populations and sources of inocula. Under such conditions, potential benefits of vector or pathogen control in olive are difficult to predict with respect to reduced incidence of disease and increase in crop yield or quality. Elsewhere, the situation may be different. In 2013, X. fastidiosa infection of olive in Italy was reported (39) but details on pathogen genotype, prevalence, and means of spread are limited. Because the European Union (16) considers $X$. fastidiosa an exotic, high risk pathogen, there is intense interest in olive as a host of $X$. fastidios $a$ and the role of olive in epidemiology of diseases caused by $X$. fastidiosa.

\section{Acknowledgments}

This research was supported by a California Olive Committee grant awarded to R. Krugner and by the United States Department of Agriculture-Agricultural Research Service appropriated project 5302-22000-010-00D. We thank T. de la Torre, M. Venegaz, and A. J. Salyers for assisting in plant and insect maintenance; G. Phillips for maintaining bacterial cultures and assisting isolation; P. Dwyer for collection of field trapping data; and Duarte nursery for donating grapevines.

\section{Literature Cited}

1. Almeida, R. P. P., Nascimento, F. E., Chau, J., Prado, S. S., Tsai, C. W., Lopes, S. A., and Lopes, J. R. S. 2008. Genetic structure and biology of $X y$ lella fastidiosa strains causing disease in citrus and coffee in Brazil. Appl. Environ. Microbiol. 74:3690-3701.

2. Almeida, R. P. P., and Purcell, A. H. 2003. Transmission of Xylella fastidiosa to grapevines by Homalodisca coagulata (Hemiptera: Cicadellidae). J. Econ. Entomol. 96:264-271.

3. Blackmer, J. L., Hagler, J. R., Simmons, G. S., and Henneberry, T. J. 2006. Dispersal of Homalodisca vitripennis (Homoptera: Cicadellidae) from a point release site in citrus. Environ. Entomol. 35:1617-1625.

4. Blua, M. J., Phillips, P. A., and Redak, R. A. 1999. A new sharpshooter threatens both crops and ornamentals. Calif. Agric. 53:22-25.

5. Chang, C. J., Garnier, M., Zreik, L., Rossetti, V., and Bové, J. M. 1993. Culture and serological detection of the xylem-limited bacterium causing citrus variegated chlorosis and its identification as a strain of Xylella fastidiosa. Curr. Microbiol. 27:137-142.

6. Chen, J., Groves, R., Civerolo, E. L., Viveros, M., Freeman, M., and Zhang, Y. 2005. Two Xylella fastidiosa genotypes associated with almond leaf scorch disease on the same location in California. Phytopathology 95:708714.

7. Chen, J., Xie, G., Han, S., Chertkov, O., Sims, D., Civerolo, E. L. 2010. Whole genome sequences of two Xylella fastidiosa strains (M12 and M23) causing almond leaf scorch in California. J. Bacteriol. 192:4534.

8. Costa, H. S., Blua, M. S., Bethke, J. A., and Redak, R. A. 2000. Transmission of Xylella fastidiosa to oleander by the glassy-winged sharpshooter, Homalodisca coagulata. HortScience 35:1265-1267.

9. Costa, H. S., Raetz, E., Pinckard, T. R., Gispert, C., Hernandez-Martinez, R., Dumenyo, C. K., and Cooksey, D. A. 2004. Plant hosts of Xylella fastidiosa in and near southern California vineyards. Plant Dis. 88:1255-1261.

10. Coviella, C. E., Garcia, J. F., Jeske, D. R., Redak, R. A., and Luck, R. F. 2006. Feasibility of tracking within-field movements of Homalodisca coagulata (Hemiptera: Cicadellidae) and estimating its densities using fluorescent dusts in mark-release-recapture experiments. J. Econ. Entomol. 99:1051-1057.

11. Daane, K. M., and Johnson, M. W. 2004. Biology and ecology of the glassy-winged sharpshooter in the San Joaquin Valley. Pages 93-96 in: Proc. Pierce's Dis. Res. Symp. Calif. Dep. Food Agric. Copeland Printing, Sacramento, CA.

12. Daane, K. M., Wistrom, C. M., Shapland, E. B., and Sisterson, M. S. 2011. Seasonal abundance of Draeculacephala minerva and other Xylella fastidiosa vectors in California almond orchards and vineyards. J. Econ. Entomol. 104:367-374.

13. Davis, M. J., French, W. J., and Schaad, N. W. 1981. Axenic culture of the bacteria associated with phony disease of peach and plum leaf scald. Curr. Microbiol. 6:309-314.

14. Davis, M. J., Purcell, A. H., and Thompson, S. V. 1978. Pierce's disease of grapevines: Isolation of the causal bacterium. Science 199:75-77.

15. Davis, M. J., Thomson, S. V., and Purcell, A. H. 1980. Etiological role of a xylem-limited bacterium causing Pierce's disease in almond leaf scorch. Phytopathology 70:472-475.

16. European and Mediterranean Plant Protection Organization. 2013. EPPO Standard PM 1/2. http://www.eppo.org/QUARANTINE/quarantine.htm

17. Hartung, J. S., Beretta, J., Brlansky, R. H., Spisso, J., and Lee, R. F. 1994. Citrus variegated chlorosis bacterium: Axenic culture, pathogenicity, and serological relationships with other strains of Xylella fastidiosa. Phytopathology 84:591-597.

18. Hernandez-Martinez, R., Cooksey, D. A., and Wong, F. P. 2009. Leaf scorch of purple-leafed plum and sweetgum dieback: Two new diseases in Southern California caused by Xylella fastidiosa strains with different host ranges. Plant Dis. 93:1131-1138.

19. Hernandez-Martinez, R., de la Cerda, K. A., Costa, H. S., Cooksey, D. A., and Wong, F. P. 2007. Phylogenetic relationships of Xylella fastidiosa strains isolated from landscape ornamentals in Southern California. Phytopathology 97:857-864.

20. Hewitt, W. B., Frazier, N. W., Freitag, J. H., and Winkler, A. J. 1949. Pierce's disease investigations. Hilgardia 19:207-264.

21. Hopkins, D. L. 1988. Xylella fastidiosa and other fastidious bacteria of uncertain affiliation. Pages 95-103 In: Laboratory Guide for Identification of Plant Pathogenic Bacteria, 2nd ed. N. W. Schaad, ed. American Phytopathological Society, St. Paul, MN.

22. Hopkins, D. L., and Purcell, A. H. 2003. Xylella fastidiosa: Cause of Pierce's disease of grapevine and other emergent diseases. Plant Dis. 86:1056-1066.

23. Krugner, R. 2010. Differential reproductive maturity between geographically separated populations of Homalodisca vitripennis (Germar) in California. Crop Prot. 29:1521-1528.

24. Krugner, R., Groves, R. L., Johnson, M. W., Flores, A. P., Hagler, J. R., and Morse, J. G. 2009. Seasonal population dynamics of Homalodisca vitripennis (Hemiptera: Cicadellidae) in sweet orange trees maintained under continuous deficit irrigation. J. Econ. Entomol. 102:960-973.

25. Krugner, R., Hagler, J. R., Groves, R. L., Sisterson, M. S., Morse, J. G., and Johnson, M. W. 2012. Plant water stress effects on the net dispersal rate of the insect vector Homalodisca vitripennis (Germar) (Hemiptera: Cicadellidae) and movement of its egg parasitoid, Gonatocerus ashmeadi Girault (Hymenoptera: Mymaridae). Environ. Entomol. 41:1279-1289.

26. Krugner, R., Ledbetter, C. A., Chen, J., and Shrestha, A. 2012. Phenology of Xylella fastidiosa and its vector around California almond nurseries: An assessment of plant vulnerability to almond leaf scorch disease. Plant Dis. 96:1488-1494.

27. Minsavage, G. V., Thompson, C. M., Hopkins, D. L., Leite, R. M. V. B. C., and Stall, R. E. 1994. Development of a polymerase chain reaction protocol for detection of Xylella fastidiosa in plant tissue. Phytopathology 84:456461.

28. Mircetich, S. M., Lowe, S. K., Moller, W. J., and Nyland, G. 1976. Etiology of almond leaf scorch disease and transmission of the causal agent. Phytopathology 66:17-24.

29. Park, Y. L., Perring, T. M., Farrar, C. A., and Gispert, C. 2006. Spatial and temporal distribution of two sympatric Homalodisca spp. (Hemiptera: Cicadellidae): Implications for areawide pest management. Agric. Ecosyst. Environ. 113:168-174.

30. Park, Y.-L., Perring, T. M., Yacoub, R., Bartels, D. W., and Elms, D. 2006. Spatial and temporal dynamics of overwintering Homalodisca coagulata (Hemiptera: Cicadellidae). J. Econ. Entomol. 99:1936-1942.

31. Perring, T. M., Farrar, C. A., and Blua, M. J. 2001. Proximity to citrus influences Pierce's disease in Temecula Valley vineyards. Calif. Agric. 55:13-18.

32. Pierce, N. B. 1892. California vine disease: A preliminary report of investigations. U.S. Dep. Agric. Div. Veg. Pathol. Bull. No. 2. Government Printing Office, Washington, DC.

33. Purcell, A. H. 1980. Almond leaf scorch: Leafhopper and spittlebug vectors J. Econ. Entomol. 73:834-838

34. Purcell, A. H., and Frazier, N. W. 1985. Habitats and dispersal of the principal leafhopper vectors of Pierce's disease in the San Joaquin Valley. Hilgardia 53:1-32.

35. Purcell, A. H., and Saunders, S. R. 1999. Fate of Pierce's disease strains of Xylella fastidiosa in common riparian plants in California. Plant Dis. 83:825-830.

36. Purcell, A. H., Saunders, S. R., Hendson, M., Grebus, M. E., and Henry, M J. 1999. Causal role of Xylella fastidiosa in oleander leaf scorch disease. Phytopathology 89:53-58.

37. Raju, B. C., Wells, J. M., Nyland, G., Brlansky, R. H., and Lowe, S. K. 1982. Plum leaf scald: Isolation, culture, and pathogenicity of the causal agent. Phytopathology 72:1460-1466.

38. Rogers, E. E. 2012. Evaluation of Arabidopsis thaliana as a model host for Xylella fastidiosa. Mol. Plant-Microbe Interact. 25:747-754.

39. Saponari, M., Boscia, D., Nigro, F., and Martelli, G. P. 2013. Identification of DNA sequences related to Xylella fastidiosa in oleander, almond and olive trees exhibiting leaf scorch symptoms in Apulia (Southern Italy). J. Plant Pathol. 95:668.

40. Scally, M., Schuenzel, E. L., Stouthamer, R., and Nunney, L. 2005. Multilocus sequence type system for the plant pathogen Xylella fastidiosa and 
relative contributions of recombination and point mutation to clonal diversity. Appl. Environ. Microbiol. 71:8491-8499.

41. Sisterson, M. S., Chen, J. C., Viveros, M. A., Civerolo, E. L., Ledbetter, C., and Groves, R. L. 2008. Effects of almond leaf scorch disease on almond yield: Implication for management. Plant Dis. 92:409-414.

42. Sisterson, M. S., Ledbetter, C. A., Chen, J., Higbee, B. S., Groves, R. L., and Daane, K. M. 2012. Management of almond leaf scorch disease: Longterm data on yield, tree vitality, and disease progress. Plant Dis. 96:10371044.

43. Sisterson, M. S., Thammiraju, S. R., Lynn-Patterson, K., Groves, R. L., and Daane, K. M. 2010. Epidemiology of diseases caused by Xylella fastidiosa in California: Evaluation of alfalfa as a source of vectors and inocula. Plant Dis. 94:827-834.

44. Sisterson, M. S., Yacoub, R., Montez, G., Grafton-Cardwell, E., and Groves, R. L. 2008. Distribution and management of citrus in California: Implications for management of glassy-winged sharpshooter. J. Econ. Entom. 101:1041-1050.

45. Sorensen, J. T., and Gill, R. J. 1996. A range extension of Homalodisca coagulata (Say) (Hemiptera: Clypeorryncha: Cicadellidae) to southern California. Pan-Pac. Entomol. 72:160-161.

46. Stenger, D. C., Sisterson, M. S., and French, R. 2010. Population genetics of Homalodisca vitripennis reovirus validates timing and limited introduction to California of its invasive insect host, the glassy-winged sharpshooter.
Virology 407:53-59.

47. Turner, W. F., and Pollard, H. N. 1959. Life histories and behavior of five insect vectors of phony peach disease. U. S. Dep. Agric. Tech. Bull. 1188:128

48. Úrbez-Torres, J. R., Peduto, F., Vossen, P. M., Krueger, W. H., and Gubler, W. D. 2013. Olive twig and branch dieback: Etiology, incidence, and distribution in California. Plant Dis. 97:231-244.

49. USDA-NASS. 2013. Noncitrus Fruits and Nuts, 2012, Preliminary Summary. USDA, National Agricultural Statistics Service. http://www.nass. usda.gov

50. Weimer, J. L. 1931. Alfalfa dwarf, a hitherto un-reported disease. Phytopathology 21:71-75.

51. Wells, J. M., Raju, B. C., and Nyland, G. 1983. Isolation, culture, and pathogenicity of the bacterium causing phony disease of peach. Phytopathology 73:859-862.

52. Wistrom, C., Sisterson, M. S., Pryor, M. P., Hashim-Buckey, J., and Daane, K. M. 2010. Distribution of glassy-winged sharpshooter and three-cornered alfalfa hopper on plant hosts in the San Joaquin Valley, California. J. Econ. Entomol. 103:1051-1059.

53. Yuan, X., Morano, L., Bromley, R., Spring-Pearson, S., Stouthamer, R., and Nunney, L. 2010. Multilocus sequence typing of Xylella fastidiosa causing Pierce's disease and oleander leaf scorch in the United States. Phytopathology 100:601-611. 